\title{
Use of the cell quota and chlorophyll content for normalization of cylindropermopsin produced by two Cylindrospermopsis raciborskii strains grown under different light intensities
}

\author{
R.L. Carneiro ${ }^{1, *}$, A.P.R. da Silva², V.F. de Magalhães ${ }^{1} \&$ S.M.F de Oliveira e Azevedo ${ }^{1}$ \\ ${ }^{1}$ Institute of Biophysics Carlos Chagas Filho, Health Sciences Center, Federal University of Rio de Janeiro - ${ }^{1}$ Laboratory of \\ Cyanobacterial Ecophysiology and Toxicology; ${ }^{2}$ Companhia Estadual de Águas e Esgotos CEDAE-RJ.
}

(Received April 18, 2012; Accept September 10, 2012)

\begin{abstract}
The production of cylindrospermopsin (CYN) by Cylindrospermopsis raciborskii (Woloszynska) Seenaya and Subba Raju (Cyanobacteria) was already shown to be changed by variations in light intensities. Influences of light intensity on CYN production by two different C. raciborskii strains (CYP011K and CYP030A) were studied in batch culture conditions. The strains were grown under photon light intensities from 40 to $348 \mu \mathrm{mol}$ photons $\mathrm{m}^{-2} \mathrm{~s}^{-1}$. The growth rates were measured by exponential regression of cell number variation along the time. The concentration of chlorophyll- $a$ (Chl- $a$ ) was measured by spectrophotometric methods and the CYN concentration was measured by high-performance liquid chromatographic methods. Data from these CYN analyses were evaluated as cell quota (ng CYN $10^{-6}$ cells) or as the relative proportion between toxin concentration and chlorophyll- $a$ concentration $\left(\mathrm{CYN} \mathrm{Chl-} a^{-1}\right)$. The CYP011K showed higher growth rates than the CYP030A strains. According to the cell quota results, the production of CYN by these two strains of C. raciborskii is not affected by the intensity of the surrounding light during growth. However, analysis of the relative proportion of CYN Chl- $a^{-1}$ led to different interpretations, as a negative relation between light intensity and CYN production.
\end{abstract}

Key words: Cylindrospermopsis raciborskii, CYN cell quota, cylindrospermopsin per Chlorophyll- $a$. Uso da normalização de cylindrospermopsina por quota celular e por clorofila em cepas de Cylindrospermopsis
raciborskii sob diferentes intensidades luminosas

\section{Resumo}

A produção de cilindrospermopsina (CYN) por Cylindrospermopsis raciborskii (Woloszynska) Seenaya e Raju Subba já foi associada a mudanças de intensidade luminosa. Neste estudo avaliamos as influências de diferentes intensidades de luz na produção de CYN por duas cepas de C. raciborskii (CYP011K e CYP030A) em cultivos fechados. As cepas foram cultivadas em intensidades luminosas de 40 a $348 \mu \mathrm{mol}$ fotóns $\mathrm{m}^{-2} \mathrm{~s}^{-1}$. As taxas de crescimento foram medidas por meio de regressão exponencial aplicada à variação do número de células ao longo do tempo. A concentração de clorofila-a (Chl- $a$ ) foi medida por métodos espectrofotométricos e a concentração de CYN foi determinada por técnicas de HPLC. Os dados das análises de CYN foram avaliados como quota celular (ng CYN $10^{-6}$ células) ou como proporção relativa entre a concentração de toxina e clorofila-a (CYN Chl- $\left.a^{-1}\right)$. A cepa CYP011K apresentou maiores taxas de crescimento do que a cepa CYP030A. De acordo com os resultados de cota celulares, a produção de CYN por estas duas linhagens de C. raciborskii não é afetada pela intensidade da luz, durante o crescimento. No entanto, a análise da proporção relativa de CYN Chl-a ${ }^{-1}$ levou a interpretações diferentes, como a aparente relação inversa entre o aumento da intensidade luminosa e a produção de CYN. Este estudo reforça o fato de que diferentes formas de normalização de dados levam a diferentes interpretações sobre a toxicologia fisiologia e ecologia de C. raciborskii.

Palavras-chave: Cylindrospermopsis raciborskii, quota celular, cilindrospermopsina por clorofila-a.

*Corresponding author: Ronaldo Leal Carneiro, e-mail: rleal@biof.ufrj.br 


\section{INTRODUCTION}

Cylindrospermopsis raciborskii is a planktonic, nitrogenfixing, bloom-forming, freshwater cyanobacterium. $C$. raciborskii has become a notorious cyanobacterium, due to its invasive capacity associated with global warming and its worldwide occurrence (Wiedner et al. 2007, Haande et al. 2008). The increased proliferation of C. raciborskii is of particular concern due to the ability to produce toxins. This species was first associated with a human poisoning incident on Palm Island, Australia, in 1979 (Hawkins et al. 1985). Subsequently, Ohtani et al. (1992) indentified a potent hepatotoxic alkaloid containing a cyclic guanidine named cylindrospermopsin $(\mathrm{CYN})$ from $C$. raciborskii strains. Since 1992, several strains of C. raciborskii from Australia and Asia have been frequently described as CYN producers (Griffiths \& Saker 2003).

C. raciborskii can grow under different sources of nitrogen and low phosphate concentrations (Padisák 1997, Saker \& Neilan 1999). Low light intensities and optically deep mixing tolerance is thought to increase its dominance (Wiedner et al. 2007, O'Brien et al. 2009). However, to different water bodies, there is not a strong correlation between $C$. raciborskii bloom and CYN concentration samples (Griffiths \& Saker 2003). Furthermore, associations between growth and CYN concentrations in environmental samples are variable and unpredictable (Griffiths \& Saker 2003).

Light intensity is considered as the growth and metabolism regulator of phytoplankton species (Reynolds 2006). Several laboratory studies on the effects of different photon density flux on toxin production by cyanobacteria have been developed. For example, in Microcystis aeruginos a production of microcystins was enhanced with increasing light intensity, with decreasing light intensity or it was not affected by light (Wiedner et al. 2003).

Light have major importance for regulating the dynamics of populations of C. raciborskii (Wiedner et al. 2007, Carneiro et al. 2009). Blooms of C. raciborskii have occurred under unsteady light intensities until to $830 \mu \mathrm{mol}$ photons $\mathrm{m}^{-2} \mathrm{~s}^{-1}$ (Bouvy et al. 1999, Briand et al. 2002) and some strains of this species could acquire advantages both in low and high light intensities (Briand et al. 2002). So, light intensity is a regulator of the growth and ability to produce toxins by C. raciborskii. However, few studies have been conducted to explain the effects of light intensity on the production of CYN under controlled conditions. Additionally, due the literature use different ways to describe C. raciborskii ecophysiology, the present study investigated the differences between CYN data normalization in two C. raciborskii strains under different light intensity.

\section{MATERIAL AND METHOD}

\section{Strain maintenance}

CYP011K and CYP030A were the two strains of $C$. raciborskii used. These strains were kindly provided by Dr.
Andrew Humpage (Australian Water Quality Centre, Australia) and their identities were confirmed as CYN producers by highperformance liquid chromatographic (HPLC) techniques. The strains were grown and stored in the culture collection of the Laboratory of Cyanobacterial Ecophysiology and Toxicology (IBCCF ${ }^{\circ}$ - UFRJ). Nonaxenic batch cultures were grown in ASM-1 medium (Gorhan et al. 1964) with aeration (provided by a compressed air pump), at $24 \pm 2{ }^{\circ} \mathrm{C}$, with photoperiods of $12 \mathrm{~h}$. These conditions were used for all experiments. Cultures of these strains were kept under photon density flux of 40 $\mu \mathrm{mol}$ photons $\mathrm{m}^{-2} \mathrm{~s}^{-1}$, provided by ordinary fluorescent light bulbs, and the light intensity was measured with a quanta sensor (QST-100 Box - Biospherical Instruments Inc.).

\section{Selection of the light intensities}

The CYP011K and CYP030A strains were grown under different light intensities prior to the experimental tests to verify their susceptibility to high light. The maximum light intensity of $100 \mu \mathrm{mol}$ photons $\mathrm{m}^{-2} \mathrm{~s}^{-1}$ for CYP011K and $348 \mu \mathrm{mol}$ photons $\mathrm{m}^{-2} \mathrm{~s}^{-1}$ for CYP030A were selected because the strains formed a lot of cell lysis when grown at higher light intensities. During the stationary phase, cultures of the CYP011K strain were maintained under photon flux densities of 40,60 and $100 \mu \mathrm{mol}$ photons $\mathrm{m}^{-2} \mathrm{~s}^{-1}$, while cultures of the CYP030A strain were maintained under photon flux densities of 100 and $348 \mu \mathrm{mol}$ photons $\mathrm{m}^{-2} \mathrm{~s}^{-1}$. The cultures were kept under these conditions for five generations, during which they were able to adapt to their respective photon flux densities. The strains were inoculated in glass balloons, with $1.010^{6}$ cells per milliliter of the ASM-1 medium (of which 2 liters were used). Each set of conditions was performed in triplicate. Before the cells were inoculated, each light intensity was measured by immersing the quanta sensor in distilled water (using the same volume as the cultures) at the bottom of a similar glass balloon.

\section{Growth measurements}

To determine the rate of cellular growths, under sterilized conditions, samples were harvested daily throughout the duration of the experiment (12 days). Cell measurements were performed under light microscopy using an ocular ruler. A few milliliters were harvested from each culture to determine the average length of a cell by randomly measuring the lengths of ninety cells. At each sampling time, samples were also used to measure the lengths of the filaments, by a Fuchs Rosenthal hemocytometer. The total length of the filaments measured was divided by the average cellular length, giving the number of cells per milliliter of culture obtained from each condition (Carneiro et al., 2011). The growth rates of the strains were determined by exponential regression of cell number variation along the time, and are presented as the relative growth rate $(\mu$ day $^{-1}$ ) (Reynolds, 2006), using the followed formula:

$$
\mathrm{N}_{\mathrm{t}}=\mathrm{N}_{0} \mathrm{e}^{\mu . \mathrm{t}}
$$

where $N_{t}$ and $N_{0}$ are the final and initial number of cells (cells $\mathrm{mL}^{-1}$ ), respectively, and $\mathrm{t}$ is the time (day). 


\section{Chlorophyll-a measurements}

Chlorophyll- $a$ (Chl- $a$ ) were determined in samples harvested under sterile conditions every three days over the course of experiment. Ten milliliters were taken from each culture and filtered using borosilicate filters $(13 \mathrm{~mm}$ diameter - Millipore). The filters were put into test tubes with $5 \mathrm{~mL}$ of pure methanol $(100 \%)$, and the resulting solutions were kept in the dark for $30 \mathrm{~min}$. The samples were then centrifuged (10000 $\mathrm{g}, 20 \mathrm{~min}, 4^{\circ} \mathrm{C}$ ) and the supernatant solutions were harvested and used to determine their optical densities in $665 \mathrm{~nm}$ (with a turbidity correction at $750 \mathrm{~nm}$ ). The $\mathrm{Chl}-a$ concentration was calculated via Mackiney's extinction coefficient (Mackiney 1941), which uses the followed formula:

$$
\mathrm{C}=\left[\left(\mathrm{OD}_{665}-\mathrm{OD}_{750}\right) \cdot \mathrm{v}\right] /(\mathrm{V} \cdot \mathrm{k} \cdot \mathrm{d})
$$

where $\mathrm{C}$ is the Chl- $a$ concentration $\left(\mu \mathrm{g} \mathrm{L}^{-1}\right), \mathrm{v}$ is the volume of methanol $(\mathrm{mL}), \mathrm{V}$ is the volume of the culture $(\mathrm{L})$, $\mathrm{k}$ is Mackiney's extinction coefficient $\left(74.5 \mathrm{~L} \mathrm{~g}^{-1} \mathrm{~cm}^{-1}\right)$, and $\mathrm{d}$ is the distance travelled by the light $(\mathrm{cm})$.

\section{CYN Analysis}

To determine the CYN concentrations, $500 \mathrm{~mL}$ samples were collected. These samples were collected on the sixth and twelfth days of culturing of each strain to represent the exponential and stationary growth phases respectively. These samples were filtered through borosilicate filters $(45 \mathrm{~mm}$ diameter - Millipore). After filtration, the cells contained in the filters were analyzed to CYN measurments. All samples were stored at $-20^{\circ} \mathrm{C}$ until they were analyzed by HPLC.

The methods used for the extraction of CYN from intracellular samples were modifications of those described by Li et al. (2001). The filter from each sample was cut into small pieces, and added to $20 \mathrm{~mL}$ of Milli-Q water. The mixtures were shaken for two hours with a magnetic workbench shaker, and were then centrifuged ( $30 \mathrm{~min}, 10000 \mathrm{~g}$ ). The supernatants were then passed through octadecylsilane cartridges (Bond Elut $\mathrm{C}_{18}$ ). Cartridges were regenerated with $20 \mathrm{~mL}$ of pure methanol $(100 \%)$, and equilibrated with $20 \mathrm{~mL}$ of ultrapure water (Milli-Q). Before samples were passed, the cartridges were eluted with $40 \mathrm{~mL}$ of Milli-Q water. The eluted fractions were then freeze-dried, liofilized, and resuspended in $2 \mathrm{~mL}$ of Milli-Q water. These suspensions were then filtered with 0.45 $\mu \mathrm{m}$ nylon filters (13 $\mathrm{mm}$ - Millipore), and the resulting pure samples were analyzed by HPLC.

The intracellular CYN were analyzed by a Shimadzu HPLC system, using a silica-base reversed phase column $(125 \mathrm{~mm}$ x $4.0 \mathrm{~mm}, 5 \mu \mathrm{m}$; Lichrospher $100 \mathrm{RP} 18)$ with a photo-diode array detector. The chromatography was performed according Welker's method (Welker et al. 2002) using a mobile phase with a polarity gradient of $0-50 \%$ water:methanol added with trifluoroacetic acid (TFA, $0.05 \%, \mathrm{~V} / \mathrm{V}$ ) over $20 \mathrm{~min}$. The CYN was detected at $262 \mathrm{~nm}$, and its identity was confirmed by comparison with known retention times and the integrated areas of the standard. This standard was purchased from the Institute of Marine Bioscience - National Research Council of Canada (Halifax, Canada).
The CYN concentrations that had been determined by HPLC were then assessed as cell quota (ngCYN $10^{-6}$ cells) and as the relative proportion between $\mathrm{CYN}$ and Chl- $a$ content (CYN Chl- $a^{-1}$ ) in order to elucidate the dynamics of the CYN production in the two different strains of $C$. raciborskii with cell number corresponding to a bloom of this species $\left(10^{6}\right.$ cells $\left.\mathrm{mL}^{-1}\right)$. The relative proportion was calculated by dividing the CYN concentration per liter $\left(\mu \mathrm{g} \mathrm{L}^{-1}\right)$ by the Chl- $a$ concentration per liter $\left(\mu \mathrm{g} \mathrm{L}^{-1}\right)$.

\section{Statistical analysis}

All of the data are expressed as mean values \pm standard error (SE). To CYP011K strain, one-way analysis of variance (ANOVA) was used to test the differences between the data of each treatment. If the ANOVA results showed that the variations were significant $(p<0.05)$, Tukey's multiple comparison tests were used to compare the values of each treatment used. In comparisons to CYP030A strain data, Student's $t$-tests were performed to determine the differences between the two observations. All tests were performed with $95 \%$ of significance $(\mathrm{p}<0.05)$ using the Statistica for windows (v9.0) application.

\section{RESULTS}

\section{Cellular growth}

In all light treatments, both strains grew exponentially until the sixth day (Fig 1). The relative growth rates are presented in Table 1. The cells of the CYP011K strain had the highest growth rate under $100 \mu \mathrm{mol}$ photons $\mathrm{m}^{-2} \mathrm{~s}^{-1}$ (ANOVA, $\mathrm{p}<0.05$ ), and this growth rate represented the highest growth rate across the two strains of $C$. raciborskii $(t$-test, $\mathrm{p}<0.05)$. Significant differences in growth rates were not seen in the cultures of CYP030A cells ( $t$-test, $\mathrm{p}>0.05)$ submitted to different light intensities.

\section{Chlorophyll-a variation}

Chl- $a$ concentrations were normalized to $10^{6}$ cells. The CYP011K strain cells under different tested photon density flux has showed the highest Chl- $a$ concentrations after the third day of culturing (Fig. 2A, ANOVA, $p<0.05$ to all treatments). In the cell cultures stored under $40 \mu \mathrm{mol}$ photons $\mathrm{m}^{-2} \mathrm{~s}^{-1}$, the concentration of Chl- $a$ doubled between the third and ninth day of growth (Fig $2 \mathrm{~A}$; $t$-test, $\mathrm{p}<0.05$ ). This trend also occurred in the cultures stored under $60 \mu \mathrm{mol}$ photons $\mathrm{m}^{-2}$ $\mathrm{s}^{-1}$ between the sixth and ninth days (Fig $2 \mathrm{~A} ; t$-test, $\mathrm{p}<0.05$ ).

The cells of the CYP011Kstrain grown under $100 \mu \mathrm{mol}$ photons $\mathrm{m}^{-2} \mathrm{~s}^{-1}$ had no change in Chl- $a$ concentration for the duration of the growth (Fig 2A; ANOVA, $\mathrm{p}>0.05$ ). This same pattern was also seen in cells of CYP030A strain exposed to the two tested photon density flux (Fig 2B; ANOVA, $p>0.05$ to the two treatments). However, in the results from the ninth day of culturing (early stationary phase), significant 
A.

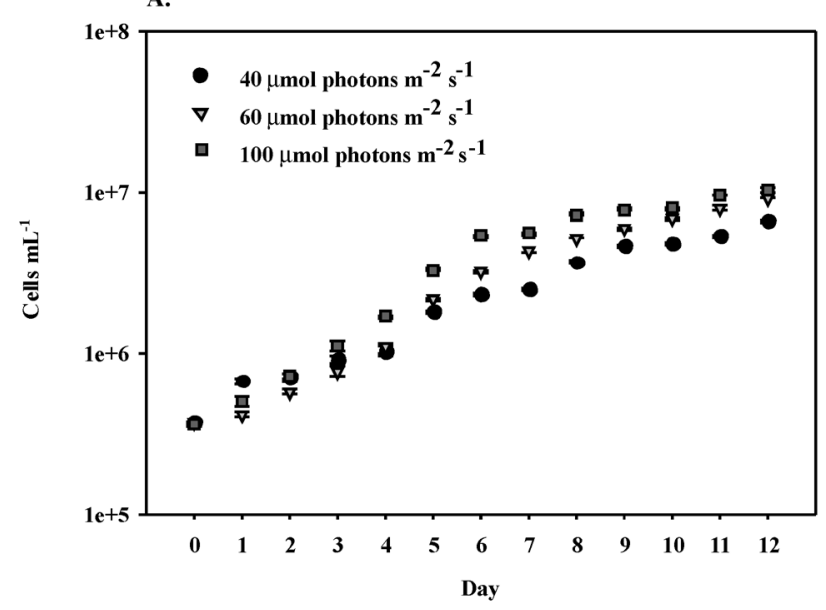

B.

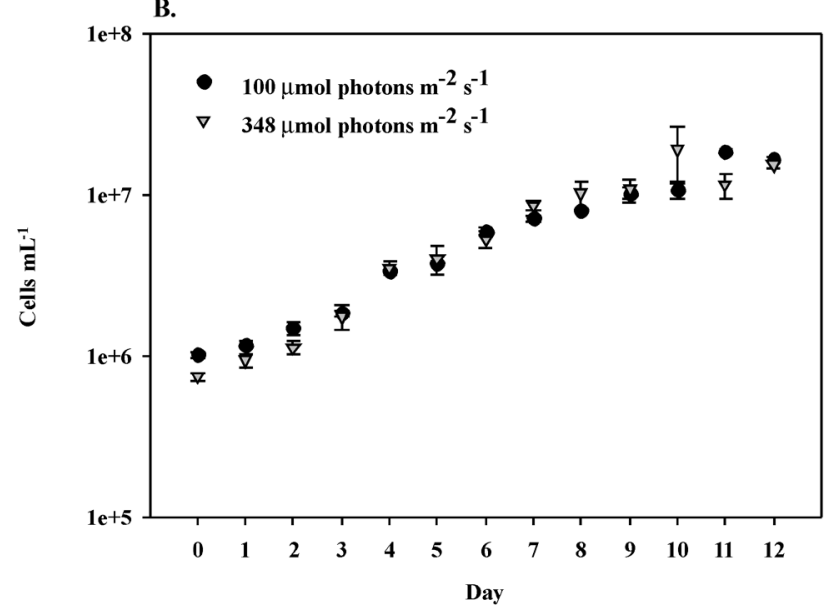

Figure 1 - Growth curves of C. raciborskii CYP011K (A) and CYP030A (B) strain cells exposed to three different light intensities. The error bars are standard errors $(n=3)$.

Table 1 - Growth rates and Chlorophyll- $a$ concentrations in C. raciborskii cells exposed to four different light intensities.

\begin{tabular}{lcccc}
\hline \multirow{2}{*}{ Strain } & \multirow{2}{*}{ Treatment $^{a}$} & \multirow{2}{*}{$\mu$, day $^{1 b}$} & \multicolumn{2}{c}{ Chl- $a\left(\mu \mathrm{g} 10^{-6}\right.$ Cells $)$} \\
\cline { 3 - 5 } & & & $9^{\text {th }}$ day & $12^{\text {th }}$ day \\
\cline { 2 - 5 } & 40 & $0.313 \pm 0.04$ & $0.324 \pm 0.01$ & $0.310 \pm 0.02$ \\
\hline CYP 011K & 60 & $0.477 \pm 0.03$ & $0.291 \pm 0.01$ & $0.251 \pm 0.03$ \\
\cline { 2 - 5 } & 100 & $0.524 \pm 0.02$ & $0.234 \pm 0.01$ & $0.210 \pm 0.02$ \\
\hline & 100 & $0.393 \pm 0.03$ & $0.113 \pm 0.02$ & $0.108 \pm 0.05$ \\
\cline { 2 - 5 } CYP 030A & 348 & $0.375 \pm 0.12$ & $0.277 \pm 0.11$ & $0.305 \pm 0.12$
\end{tabular}

Data is presented with average \pm standard error $(\mathrm{n}=3) .{ }^{a}$ The light intensities are given in $\mu \mathrm{mol}$ photons $\mathrm{m}^{-2} \mathrm{~s}^{-1} \cdot{ }^{b} \mu$ is relative growth $\cdot$ day $^{-1}$.

differences between two samples from the different strains that were kept under $100 \mu \mathrm{mol}$ photons. $\mathrm{m}^{-2} \cdot \mathrm{s}^{-1}$ were observed (Table 1). The Chl- $a$ concentration in the CYP011K strain cells was two times that of the CYP030A strain cells (Fig 2B, $t$-test; ninth day, $\mathrm{p}<0.05$, twelfth day, $\mathrm{p}<0.05$ ).

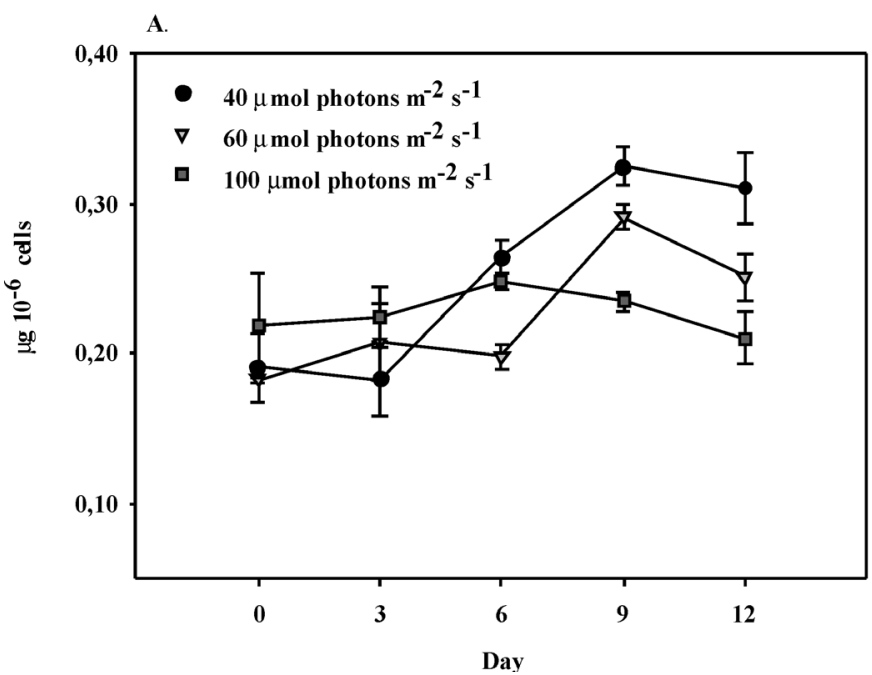

\section{The influence of light intensity on CYN production by $C$. raciborskii}

The intracellular CYN measurements as cell quota are given in table 2 .

In both the exponential and the stationary phase, cells of both strains did not present any significant differences in the $\mathrm{CYN}$ cell quota (CYP011K, ANOVA, $\mathrm{p}>0.05$; CYP030A, $t$-test, $\mathrm{p}>0.05$ ). These results clearly show that the production of CYN by both of these strains of $C$. raciborskii is not affect by the intensity of the light to which they are exposed during growth.

Results of CYN production as the proportion between CYN Chl- $a^{-1}$ are given in table 2. These results show a significant decrease in the relative proportion CYN Chl- $a^{-1}$ of the CYP011K strain cells kept under $100 \mu \mathrm{mol}$ photons $\mathrm{m}^{-2} \mathrm{~s}^{-1}$ during the exponential phase, as compared to that of 40 and $60 \mu \mathrm{mol}$ photons $\mathrm{m}^{-2} \mathrm{~s}^{-1}$ (Tukey's-test, $\mathrm{p}<0.05$ for both). Decreases in the relative proportion CYN Chl- $a^{-1}$ were

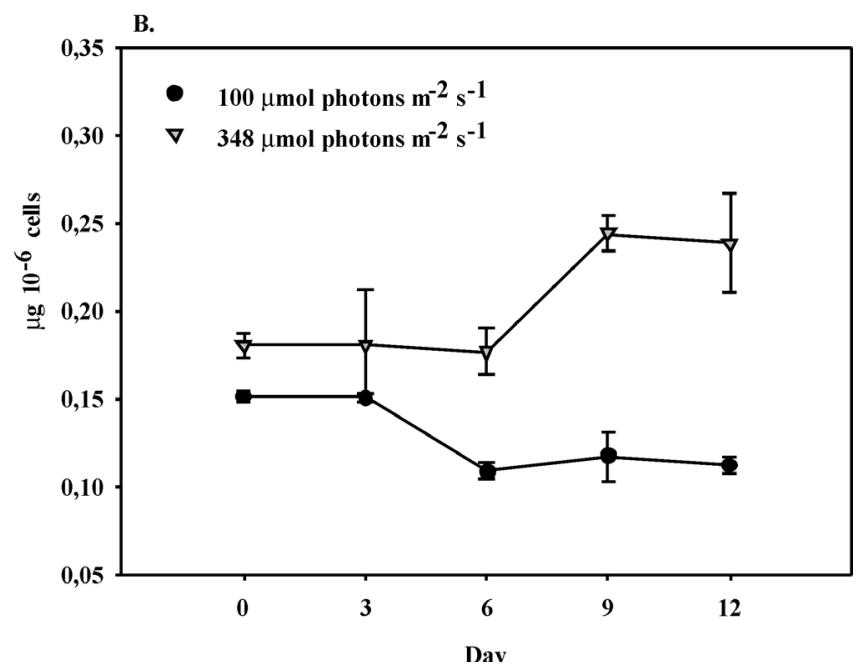

Figure 2 - Chlorophyll- $a$ variation in C. raciborskii CYP011K (A) and CYP030A (B) strain cells exposed to three different light intensities. The error bars are standard errors $(\mathrm{n}=3)$. 
Table 2 - Values of CYN data from the two different C. raciborskii strains at different phases of growth.

\begin{tabular}{|c|c|c|c|c|c|}
\hline \multirow{3}{*}{ Strain } & \multirow{3}{*}{ Treatment $^{a}$} & \multicolumn{2}{|c|}{ Cell quota } & \multicolumn{2}{|c|}{ Proportion } \\
\hline & & \multicolumn{2}{|c|}{ ng $10^{-6}$ cells } & \multicolumn{2}{|c|}{ CYN Chl- $a^{-1}$} \\
\hline & & $6^{\text {th }}$ day & $12^{\text {th }}$ day & $6^{\text {th }}$ day & $12^{\text {th }}$ day \\
\hline \multirow{3}{*}{ CYP 011K } & 40 & $24.687 \pm 9.51$ & $17.538 \pm 3.06$ & $0.092 \pm 0.002$ & $0.056 \pm 0.003$ \\
\hline & 60 & $18.853 \pm 6.00$ & $16.524 \pm 1.16$ & $0.094 \pm 0.001$ & $0.067 \pm 0.006^{*}$ \\
\hline & 100 & $12.112 \pm 5.55$ & $14.189 \pm 2.44$ & $0.049 \pm 0.002 * *$ & $0.068 \pm 0.008^{*}$ \\
\hline \multirow{2}{*}{ CYP 030A } & 100 & $5.731 \pm 1.40$ & $5.065 \pm 1.04$ & $0.053 \pm 0.007$ & $0.106 \pm 0.003$ \\
\hline & 348 & $3.179 \pm 0.67$ & $5.369 \pm 2.19$ & $0.021 \pm 0.003^{*}$ & $0.016 \pm 0.005^{* *}$ \\
\hline
\end{tabular}

${ }^{a}$ Data are presented as average of $\mathrm{CYN} \pm$ standard error $(\mathrm{n}=3)$. The light intensities are given in $\mu \mathrm{mol}$ photons $\mathrm{m}^{-2} \mathrm{~s}^{-1}$. ${ }^{*}$ Statistical differences $(\mathrm{p}<0.05),{ }^{* *}$

also observed in the exponential and stationary phases of the CYP030A strain ( $t$-test, $\mathrm{p}<0.05$ and $\mathrm{p}<0.01$, respectively). However, significant increases in the relative proportion CYN Chl- $a^{-1}$ of the CYP011K strain was observed when cells were kept under 60 and $100 \mu \mathrm{mol}$ photons $\mathrm{m}^{-2} \mathrm{~s}^{-1}$ and reached to their stationary phases (Tukey's-test, $\mathrm{p}<0.05$ for both).

These observations showed that the CYN production decreases with increased light intensity for the CYP030A strain. However, the relationship between these two factors was shown to vary according the growth phase in the case of the CYP011K strain.

\section{Variation of CYN production between the different phases of growth}

To verify the changes in the production of CYN between the two different phases of growth, the percentages of CYN production in the stationary phase were compared with those of the exponential growth phase for each strain. To simplify the observations, data with statistical tests are listed in Table 3. In summary, the CYN production by the CYP011K strain was reduced in cyanobacteria grown under lower photon density flux (Table 3), as is confirmed by the data in terms of cell quota and the ratio of CYN Chl- $a^{-1}$. However, the CYN production in the CYP011K strain was higher under $100 \mu \mathrm{mol}$ photons $\mathrm{m}^{-2} \mathrm{~s}^{-1}$. This same effect was also observed with the CYP030A strain, although this is only apparent when the data is evaluated as the proportion CYN Chl- $a^{-1}$. Interestingly, at the highest photon density flux in the CYP030A strain $\left(348 \mu \mathrm{mol}\right.$ photons $\mathrm{m}^{-2}$ $\left.\mathrm{s}^{-1}\right)$, the CYN production can be viewed as both reduced and increased, based on the $\mathrm{CYN}$ content normalization.

\section{Comparison of the CYN production between the studied strains}

It is clear that the trends in CYN production seen with the CYP030A strain are different from those observed with the CYP011K strain. In fact, at the same light intensity (100 $\mu$ mol photons $\mathrm{m}^{-2} \mathrm{~s}^{-1}$ ), the CYP011K strain produced 2.1 times more CYN per cell than the CYP030A strain (table 3, t-test, $\mathrm{p}<0.05$ ) during the exponential phase. This trend continued to the stationary phase, for which the CYN content per cell in the CYP011K strain was 2.8 times higher than that of the CYP030A strain cells (table 3 , $t$-test; $\mathrm{p}<0.01$ ).

While these trends are apparent, they must be verified by looking to the CYN Chl- $a^{-1}$ proportion. In the exponential phase, the CYP030A strain's CYN Chl- $a^{-1}$ ratio was 0.06 times higher than that of the CYP011K strain (table 3, t-test, $\mathrm{p}>0.05)$. This difference became greater during the stationary phase, during which the CYN Chl- $a^{-1}$ proportion in the CYP030A strain increased to 1.56 times higher than that of the CYP11K strain (table 3, t-test, $\mathrm{p}<0.01$ ).

\section{DISCUSSION}

Our results emphasize the fact that different normalizations of the cyanotoxin data can lead to different conclusions about

Table 3 - Percentages between determined CYN at stationary phase in relation to exponential phase of two C. raciborskii strains.

\begin{tabular}{|c|c|c|c|}
\hline \multirow{2}{*}{ Strain } & \multirow{2}{*}{ Treatment $^{a}$} & Cell quota & Proportion \\
\hline & & ng $10^{-6}$ cells & CYN Chl- $a^{-1}$ \\
\hline \multirow{3}{*}{ CYP $011 \mathrm{~K}$} & 40 & $-19.2 \% \pm 3.8 *$ & $-38.8 \% \pm 8.5^{*}$ \\
\hline & 60 & $-14.7 \% \pm 2.3 *$ & $-29.2 \% \pm 4.8^{*}$ \\
\hline & 100 & $23.2 \% \pm 2.2 *$ & $39.8 \% \pm 3.2 *$ \\
\hline \multirow{2}{*}{ CYP 030A } & 100 & $-7.5 \% \pm 2.6^{*}$ & $101.3 \% \pm 18.2 * *$ \\
\hline & 348 & $64.1 \% \pm 3.4 * *$ & $-27.3 \% \pm 4.2 *$ \\
\hline
\end{tabular}

${ }^{a}$ Data are presented as average of $\mathrm{CYN} \pm$ standard error $(\mathrm{n}=3)$. The light intensities are given in $\mu \mathrm{mol}$ photons $\mathrm{mm}^{-2} \mathrm{~s}^{-1}$. $*$ Statistical differences $(\mathrm{p}<0.05), * *$ Statistical differences $(\mathrm{p}<0.01)$. Negative values represent decreases in the production of CYN (stationary phase). 
the physiology and toxin production of a cyanotoxin-producing species. Regarding to the growth of $C$. raciborskii strains, under laboratory conditions, this species was previously reported to have optimal growth at 121 or $240 \mu \mathrm{mol}$ photons $\mathrm{m}^{-2} \mathrm{~s}^{-1}$ (Dokuli \& Mayer 1996), $80 \mu \mathrm{mol}$ photons $\mathrm{m}^{-2} \mathrm{~s}^{-1}$ (Padisák 1997, Dyble et al. 2006) or $118 \mu \mathrm{mol}$ photons $\mathrm{m}^{-2} \mathrm{~s}^{-1}$ (Saker et al. 1999). Wiedner et al. (2007) demonstrated that $C$. raciborskii requires light intensities between 80 and $120 \mu \mathrm{mol}$ photons $\mathrm{m}^{-2} \mathrm{~s}^{-1}$ in order to maximize growth, however, this cyanobacterium can achieve close to these maximum growth rates with light intensities of up $500 \mu \mathrm{mol}$ photons $\mathrm{m}^{-2} \mathrm{~s}^{-1}$. In this way, $C$. raciborskii is tolerant of high light intensities. Higher relative growth rates were seen during the exponential growth phase of the CYP011K strain when exposed to higher intensities of light (from 40 to $100 \mu \mathrm{mol}$ photons $\mathrm{m}^{-2} \mathrm{~s}^{-1}$ ). The CYP030A strain had a lower growth rate at $100 \mu \mathrm{mol}$ photons $\mathrm{m}^{-2} \mathrm{~s}^{-1}$ than that of the CYP011K strain, which seem confirms that the growth rate of $C$. raciborskii could be strain specific. C. raciborskii could be efficient at capturing light, which would allow it to survive in environments with low intensities of light (Padisák 1997). Regarding morphology, while $C$. raciborskii CYP011K exhibited a great number of cell lyses at $100 \mu \mathrm{mol}$ photons $\mathrm{m}^{-2} \mathrm{~s}^{-1}$, the CYP030A strain showed no negative effects due to the intensity of the light under which they were grown until $348 \mu \mathrm{mol}$ photons $\mathrm{m}^{-2} \mathrm{~s}^{-1}$.

In low-intensity environments, increases in Chl- $a$ production would be sufficient to maintain a steady growth rate. Higher Chl- $a$ concentrations were seen in CYP011K strain cells at lower intensities of light ( 40 and $60 \mu \mathrm{mol}$ photons $\mathrm{m}^{-2} \mathrm{~s}^{-1}$ ). This confirms Padisák's (Padisák 1997) hypothesis because under intensities of $100 \mu \mathrm{mol}$ photons $\mathrm{m}^{-2} \mathrm{~s}^{-1}$ and above, CYP030A strain cells showed no significant increases in Chl- $a$ concentration at any point in their growth. However, under the lowest intensities of light, the Chl- $a$ concentration duplicated during the growth of the CYP011K strain cells. In batch cultures, the uneven spread of light caused by cell shadings in the upper layers is a recurring problem. The consequence of this is the increase in the Chl- $a$ concentration of the cells in order to supply the additional energy required due to the decrease in external lighting (Reynolds, 2006). If high intensities of light can maintain normal growth levels and solve the problems associated with cell shadings, increase in the Chl- $a$ concentration hardly ever is observed (Reynolds, 2006), as seen in cells of the CYP011K strain that were exposed to $100 \mu \mathrm{mol}$ photons $\mathrm{m}^{-2} \mathrm{~s}^{-1}$ and in cells of the CYP030A strain that were exposed to 100 and $348 \mu \mathrm{mol}$ photons $\mathrm{m}^{-2} \mathrm{~s}^{-1}$.

The relationship between CYN production and light intensity has already been investigated in C. raciborskii strains. In a review, Griffiths and Saker (2003) explained that despite the fact that $C$. raciborskii cells can grow better when exposed to intensities of light between 50 and 100 $\mu \mathrm{mol}$ photons $\mathrm{m}^{-2} \mathrm{~s}^{-1}$, the highest CYN cellular content is obtained when the cells are exposed to higher intensities of light. This observation suggests that the relationship between the CYN production increment and increased light intensity is proportional. More recently, Dyble et al. (2006) described a linear relationship between the intensity of the light when cells are exposed to light from 18 to $75 \mu \mathrm{mol}$ photons $\mathrm{m}^{-2} \mathrm{~s}^{-1}$. Intracellular CYN production per Chl- $a$ content increased at the eighth and sixteenth days of culturing of the C. raciborskii strain SDS (which was grown in a nitrogen-free medium). No relationship was seen when the CYN production in each of the two strains studied in this work was evaluated as a cell quota (CYN $10^{-6}$ cells). From our results, it is possible to confirm that these two strains of C. raciborskii (CYP011K and CYP030A) are not affected by the intensity of the light to which they are exposed during growth.

If the CYN production of the two studied strains is evaluated as the CYN Chl- $a^{-1}$ proportion, it often elucidates the negative relationship between CYN production and the intensity of light. This is still true, even taking into account that the CYP030A strain produced about two times less Chl- $a$ per cell than the CYP011K strain. The mathematical conversion of the CYN data to a proportion of the Chl- $a$ content probably does not reflect the real behavior of the cyanotoxin production. In any case, whether viewing it as a cell quota or as the CYN Chl- $a^{-1}$ proportion, the CYN production by CYP011K and CYP030A are different from those previously reported in the literature. However, cells grown in nitrogen-free media had high CYN contents (on a cell dry-weight basis) as compared with cells grown in media with nitrogen sources (Saker \& Neilan 2001, Griffiths \& Saker 2003). Therefore, it is possible that different amounts of CYN are produced by $C$. raciborskii based on environmental factors such as the presence of nitrogen in the medium.

According to Hawkins et al. (2001), the growth phases of $C$. raciborskii are also important because the CYN could be produced differently during the exponential and stationary phases under different environmental stimuli. CYN concentrations per cell dry-weight of four strains of $C$. raciborskii produced more $\mathrm{CYN}$ during the exponential phase (Reynolds, 2006). Dyble et al. (2006) described a proportional CYN accumulation (CYN Chl- $a^{-1}$ ) from the eighth to the sixteenth days of culturing the cells with the C. raciborskii strain SDS that was kept in a nitrogen-free medium, at several different intensities of light $(35,75,53$ and $140 \mu \mathrm{mol}$ photons $\mathrm{m}^{-2} \mathrm{~s}^{-1}$ ). This data suggests the accumulation of CYN during the stationary phase. When analyzing the production of CYN as a cell quota (CYN $10^{6}$ cells) or as the CYN Chl- $a^{-1}$ proportion, we noted the different variations in CYN production based on the intensity of the light and on the strain (Table 2). In summary, our results clearly demonstrate that different conclusions can be made, depending on the normalization of the data, to explain the effects of light on CYN production by C. raciborskii.

Neilan et al. (2003) found three separated phylotypes of $C$. raciborskii strains that are CYN producers, in Australia, Europe and North and South America, based in the 16S rRNA gene nucleotide sequences. Chonudomkul et al. (2004) explained that toxin the production by twenty-four different strains of $C$. raciborskii were polyphyletic when their similarities in short repetitive sequences in the genes were analyzed. Recently, Stucken et al. (2009) showed that there is no correlation 
between toxic phenotypes and phylogenetic association in the Australian strains. The results from these previous studies show that different strains of $C$. raciborskii can have different rates of toxin production. These observations agree with our results, as two different strains stored under a same intensity of light $\left(100 \mu \mathrm{mol}\right.$ photons $\left.\mathrm{m}^{-2} \mathrm{~s}^{-1}\right)$ produced significantly different CYN concentration per cell. According Reynolds (2006), growth measurements at the different bases (e.g. dry-weight, chlorophyll- $a$, optical density) provide a larger problem and are responsible for the loss of species-specific physiological information. The conclusions formed based on the CYN Chl- $a^{-1}$ proportion are most likely extraneous, for the reasons discussed above.

\section{CONCLUSION}

The production of cylindrospermopsin by the two $C$. raciborskii strains represented in this work is not effected by light intensity.

\section{ACKNOWLEDGEMENTS}

The authors would like to thank CAPES and CNPq for their fellowships and financial support. Research was sponsored by FAPERJ (grant no. E26/100.613/2007) and by CNPq (grant no. 410765/2006-6).

\section{REFERENCES}

BOUVY, M.; MOLICA, R. J. R., OLIVEIRA, S., MARINHO, M. \& BEKER, B., 1999. Dynamics of a toxic cyanobacterial bloom (Cylindrospermopsis raciborskii) in a shallow reservoir in the semiarid region of northeast Brazil. Aquat. Microb. Ecol. 20: 285-297. http://dx..org/10.3354/ame020285

BRIAND, J. F., ROBILLOT, C., QUILBIER-LLOBERAS, C., HUMBERT, J. F., COUTÉ, A. \& BERNARD, C., 2002. Environmental context of Cylindrospermopis raciborskii (Cyanobacteria) blooms in a shallow pond in France. Water Res. 36: 3183-3192. http://dx..org/10.1016/S0043-1354(02)00016-7

BRIAND, J. F., LEBOULANGER, C., HUMBERT, J. F., BERANRD, C. \& DUFOUR, P., 2004. Cylindrospermopis raciborskii (Cyanobacteria) invasion at mid latitudes: selection, wide physiological tolerance, or global warming?. J. Phycol. 40: 231-238. http://dx..org/10.1111/j.1529-8817.2004.03118.x

CHONUDOMKUL, D., YONGMANITCHAI, W., THEERAGOOL, G., KAWACHI, M., KASAI, F., KAYA, K. \& WATANABE, M. M., 2004. Morphology, genetic diversity, temperature tolerance and toxicity of Cylindrospermopsis raciborskii (Nostocales, Cyanobacteria) strains from Thailand and Japan. FEMS Microbiol. Ecol. 48: 345- 355. http://dx..org/10.1016/j. femes.2004.02.014

CARNEIRO, R. L., SANTOS, M. E. V., PACHECO, A. B. F. \& AZEVEDO, S. M. F. O., 2009. Effects of light intensity and light quality on growth and circadian rhythm of saxitoxins production in Cylindrospermopsis raciborskii (Cyanobacteria). J. Plank. Res. 31(5): 481-488. http://dx..org/10.1093/plankt/fbp006

CARNEIRO, R. L., ALÍPIO, A.C.N., Bisch, P.M., AZEVEDO, S. M. F. O. \& PACHECO, A. B. F., 2011. The inhibitory effect of calcium on Cylindrospermopsis raciborskii (Caynobacteria) metabolism. Braz.J. Mircobiol. 42: 1547-1559.
DOKULIL, M. T. \& MAYER, J., 1996. Population dynamics and photosynthetic rates of a Cylindrospermopsis - Limnothrix association in a higly eutrophic urban lake, Alte Donau, Austria. Algol. Studies 83: 179-195.

DYBLE, J., TESTER, P. A. \& LITAKER, R. W., 2006. Effects of light intensity on cylindrospermopsin production in the cyanobacterial HAB species Cylindrospermopsis raciborskii. Afr. J.Mar. Sci. 28(2): 309-312. http://dx..org/10.2989/18142320609504168

GORHAN, P. R., MACLACHLAV, J. R., HAMMER, V. T. \& KIM, W. K., 1964. Isolation and culture of toxic strains of Anabaena flos-aquae (Lyngb.) de Bréb. Verh. Internat. Verein. Theor. Angew. Limnol. 15: 796-804.

GRIFFITHS, D. J. \& SAKER, M. L., 2003. The palm island mystery disease 20 years on: a review or research on the cyanotoxin cylindrospermopsin. Environ. Toxicol. 18 (2): 78-93. http://dx. org/10.1002/tox.10103

HAANDE, S., ROHRLACK, T., BALLOT, A., ROBERG, K., SKULBERG, R., BECK, M. \& WIEDNER, C., 2008. Genetic characterization of Cylindrospermopsis raciborskii (Nostocales, Cyanobateria) isolates from Africa and Europe. Harmful Algae 7: 692-701. http://dx..org/10.1016/j.hal.2008.02.010

HAWKINS, P. R., RUNNEGAR, M. T. C., JACKSON, A. R. B. \& FALCONER, I. R., 1985. Severe hepatotoxicity caused by the tropical cyanobacterium (blue-green alga) Cylindrospermopsis raciborskii (Woloszynska) Seenaya and Subba Raju isolated from a domestic water supply reservoir. Appl. Environ. Microbiol. 50: 1292-1295.

HAWKINS, P. R., PUTT, E., FALCONER, I. R. \& HUMPAGE, A., 2001. Phenotypical variation in a toxic strain of the phytoplankter Cylindrospermopsis raciborskii (Nostocales, Cyanophyceae) during batch culture. Environ. Toxicol. 16(6): 460-467. http:// dx..org/10.1002/tox.10005

LI, R., CARMICHAEL, W. W., BRITTAIN, S., EAGLESHAM, G. K., SHAW, G. R., LIU, Y. \& WATANABE, M. M., 2001. First report of the cyanotoxins cylindrospermopsin and deoxycylindrospermopsin from Rhaphidiopsis curvata (Cyanobacteria). J. Phycol. 37: 1121-1126. http://dx.. org/10.1046/j.1529-8817.2001.01075.x

MACKINEY, G., 1941. Absorption of light by chlorophyll solutions. J. Biol. Chem. 140: 315-322.

NEILAN, B. A., SAKER M. L., FASTNER, J., TÖRÖKNÉS, A. \& BURNS, B. P. (2003). Phylogeography of the invasive cyanobacterium Cylindrospermopsis raciborskii. Mol. Ecol. 12: 133-140. http://dx..org/10.1046/j.1365-294X.2003.01709.x

O'BRIEN, K. R., BURFORD, M. A. \& BROOKES, J. D., 2009. Effects of light history on primary productivity in a phytoplankton community dominated by toxic cyanobacterium Cylindrospermopsis raciborskii. Freshwater Biol. 54: 272-282. http://dx..org/10.1111/j.1365-2427.2008.02106.x

OHTANI, R. E., MOORE, D. \& RUNNEGAR, M. T. C., 1992. A potent hepatotoxin from the blue-green alga Cylindrospermopsis raciborskii. J. Am. Chem. Soc. 114: 7941-7942. http://dx. org/10.1021/ja00046a067

PADISÁK, J., 1997. Cylindrospermopsis raciborskii (Wolosynska) Seenaya and Subba Raju, an expading, higly adaptative cyanobacterium: worldwide distribution and review of its ecology. Archiv für Hydrobiologie 107: 563-593.

REYNOLDS, C. S. (ed.) 2006. Ecology of phytoplankton: ecology, biodiversity and conservation. Cambridge University Press, New York, USA. Pp 138-236.

SAKER, M. L., NEILAN, B. A. \& GRIFFITHS, D. J., 1999. Two morphological forms of Cylindrospermopsis raciborskii (Cyanobacteria) isolated from Solomon Dam, Palm Island, Queensland. J. Phycol. 35: 599-606. http://dx..org/10.1046/ j.1529-8817.1999.3530599.x 
SAKER, M. L. \& NEILAN, B. A., 2001. Varied diazotrophies, morphologies and toxicities of genetically similar isolates of Cylindrospermopsis raciborskii (Nostocales, Cyanophyceae) from northern Australia. Appl. Environ. Microbiol. 67: 18391845. http://dx..org/10.1128/AEM.67.4.1839-1845.2001

STUCKEN, K., MURILLO, A. A., SOTO-LIEBE, K., FUENTESVALDÉS, J. J., MÉNDEZ, M. A. \& VÁSQUEZ, M., 2009. Toxicity phenotype does not correlate with phylogeny of Cylindrospermopsis raciborskii strains. Syst. Appl. Microbiol. 32: 37-48. http://dx..org/10.1016/j.syapm.2008.10.002

WELKER, M., BICKEL, H. \& FASTNER, J. (2002). HPLC-PDA detection of cylindrospermopsin - opportunities and limits.
Water Res. 36: 4569-4663. http://dx..org/10.1016/S00431354(02)00194-X

WIEDNER, C., VISSER, P. M., FASTNER, J., METCALF, J. S., CODD, G. A. \& MUR, L. R., 2003. Effects of light on the microcystin content of Microcystis strain PCC 7806. Appl. Environ. Microbiol. 69(3): 1475-1481. http://dx..org/10.1128/ AEM.69.3.1475-1481.2003

WIEDNER, C., RÜCKER, J., BRÜGGEMANN, R. \& NIXDORF, B., 2007. Climate change affects timing and size of populations of an invasive cyanobacterium in temperate regions. Oecol. 152: 437-484. http://dx..org/10.1007/s00442-007-0683-5 